\title{
A comunicação de marca entre a publicidade de ontem e as novas gerações de consumidores: tensões e transformações. ${ }^{1}$
}

\section{The brand communication between yesterday's advertising and new generations of consumers: tensions and transformations ${ }^{2}$}

\author{
DOI: 10.46814/lajdv3n5-017
}

Recebimento dos originais: 01/05/2021

Aceitação para publicação: 31/06/2021

\section{Sandra Maria Ribeiro de Souza}

Livre-Docente e Professora Sênior da Escola de Comunicações e Artes da Universidade de São

Paulo, Departamento de Relações Públicas, Propaganda e Turismo,

Universidade de São Paulo, São Paulo, SP

E-mail: smrdsouz@usp.br

\section{RESUMO}

A publicidade se encontra em processo de transformação impulsionada, por um lado, pelo uso crescente de tecnologias da informação nas relações interpessoais e de consumo, e por outro, pela quebra das fronteiras rígidas entre as disciplinas de comunicação, decorrente do surgimento de formatos híbridos de ações marcárias, tanto em objetivos quanto em linguagem. O case Devassa Bem Loura, escolhido como exemplar das transformações em curso, ilustra a fase atual da publicidade em tensão entre esquemas criativos do passado e tendências inovadoras de difusão e persuasão.

Palavras-chave: publicidade, inovação, Devassa, celebridade, conceito de marca.

\begin{abstract}
The advertising industry is undergoing a transformation process driven, on the one hand, by the growing use of information technologies in interpersonal and consumer relations, and on the other hand, by the breakdown of rigid boundaries between communication disciplines, resulting from the emergence of hybrid formats of branding actions, both in objectives and language. The Devassa Bem Loura case, chosen as an example of the ongoing transformations, illustrates the current phase of advertising in tension between past creative schemes and innovative trends of diffusion and persuasion.
\end{abstract}

Key words: advertising, innovation, Devassa, celebrity, brand concept.

\section{INTRODUÇÃO}

O desafio da publicidade neste século é estabelecer novas relações com os consumidores, relações que não se baseiem tanto nas mensagens que os anunciantes querem transmitir, geralmente unilaterais, invasivas e persuasivas, mas sim na comunhão destas com as informações que os

\footnotetext{
1 Trabalho apresentado no II Propesq PP - Encontro de Pesquisadores em Publicidade e Propaganda, na Escola de Comunicações e Artes da Universidade de São Paulo (ECA USP).

${ }^{2}$ Paper presented at the II Propesq PP - Meeting of Researchers in Advertising and Publicity, at Escola de Comunicações e Artes da Universidade de São Paulo (ECA USP).
} 
consumidores desejam ter, com rapidez, veracidade, diversão e, acima de tudo, com conteúdo situado fora dos limites estreitos dos discursos institucionais de venda da marca.

Este desafio implica na revisão dos velhos esquemas persuasivos desenvolvidos e aperfeiçoados em pouco mais de 200 anos de propaganda (se considerarmos 1808 o ano inaugural da atividade publicitária no país com a publicação do primeiro classificado imobiliário no jornal A Gazeta do Rio de Janeiro $^{3}$ ) e na instauração de novos modos de comunicação da marca com seus consumidores que, a partir da adoção de novas tecnologias da informação em suas vidas cotidianas, em suas interações pessoais e relações de consumo, têm demonstrado mais poder sobre as mensagens que querem receber, quando querem receber e como vão reagir a elas.

É representativa dos velhos esquemas publicitários a comunicação centrada nos seguintes pilares: o comportamento de massa; o modelo intrusivo das mensagens publicitárias nos meios de comunicação; a USP, unique selling proposition ou argumentação única de venda, geralmente centrada no produto ou na promessa de transformação mágica decorrente do seu uso; a criação baseada em slogans inteligentes e imagens visuais para chamar atenção e associar produtos a características desejáveis e o predomínio da publicidade sobre outras disciplinas de comunicação de marketing, claramente definidas em termos de fronteiras e de investimentos.

Porém, há duas décadas pelo menos, novas gerações de consumidores, acostumados a computadores, celulares e demais dispositivos eletrônicos de acesso à informação e conexão em tempo real têm provocado tensões nesses antigos e padronizados esquemas persuasivos das marcas, obrigando empresas e agências de comunicação a repensarem os modelos operativos que praticam em nome da competição entre marcas e da conquista da fidelidade dos consumidores a essas mesmas marcas. A internet e a world web wide representam, para a publicidade, a democratização da comunicação de marca, pois ampliam a possibilidade e a capacidade de qualquer pessoa, consumidora ou não, de criar e distribuir conteúdos para muitos membros da sociedade (uma a um, um para muitos, muitos para muitos), desafiando a economia da atenção pela qual interatividade significa, do ponto de vista do outro, passar pelos crivos da procura e seleção das informações e conteúdos que interessam (entendase, que divirtam, emocionem) e o descarte dos demais que não preenchem os requisitos da atenção, motivação e interesse, geralmente imediatos ao acesso ${ }^{4}$.

\footnotetext{
${ }^{3}$ Segundo Ricardo Ramos, o primeiro anúncio publicado no país foi para anunciar a venda de um imóvel: "Quem quizer comprar huma morada de cazas de sobrado com frente para Santa Rita falle com Anna Joaquina da Silva, que mora nas mesmas cazas, ou com o Capitão Francisco Pereira de Mesquita que tem ordem para as vender”, conforme fac-símile publicado em GRACIOSO, F.; WHITAKER, P. Propaganda Brasileira. São Paulo: Mauro Ivan editorial, 2004 , p.20.

4 “[...]as primeiras agências brasileiras (offline) a usar a internet nos projetos e campanhas foram a J.Walter Thompson, Almap, DM9, DPTO e a Publicis, entre os anos de 1995 e 1996. Por volta de 2000, a JWT passou suas operações de web na América Latina para a agência digital CollectiveMind, trazendo para o país a JWT@Digital. Nessa mesma época, a FNazca também se digitalizou, assim como a Grottera - surgindo a Grottera.com - muitas dessas já não existem ou mudaram
} 
Este cenário já seria suficiente para a listagem de algumas tensões no exercício prático da publicidade tal qual nós, da ECA-USP, aprendemos e ensinamos há quatro décadas, mas que ainda não estão bem definidas a ponto de termos uma resposta cabal à pergunta: como anda a publicidade? Ou ainda, como andará a publicidade daqui a vinte anos?

Para complicar ainda mais o cenário da atividade nesses tempos de transformações dos modelos tradicionais, é preciso considerar que, além dos consumidores da marca agrupados por características comuns em público-alvo das campanhas publicitárias, método comum de trabalho praticado desde os anos 50 do século passado, outros grupos de pessoas passaram a se tornar relevantes para a construção estratégica da marca dentro da perspectiva do marketing de relacionamentos que é a de criar relações rentáveis e satisfatórias para todos os agentes envolvidos (o meio ambiente mercadológico ${ }^{5}$ ) e não apenas para a promotora da marca: os fãs da marca, os influenciadores de opinião, os que têm voz e seguidores nas redes sociais, os prescritores e profissionais que têm autoridade reconhecida em determinada área do saber ou fazer, enfim, vários outros subgrupos de consumidores e nãoconsumidores, que mesmo menores ou localizados, são igualmente importantes para garantir confiança, intimidade e percepção de valor sobre a marca trabalhada pelo marketing e pela comunicação.

O marketing de depois de amanhã (CAVALLINI, 2006) resume assim as transformações em curso: a) maior acesso do consumidor à informação para conhecer, questionar, comparar e divulgar sua opinião sobre produtos, serviços, marcas e empresas; b) enfraquecimento da distinção entre vida pessoal e profissional, esfera pública e privada, mundo virtual e real, pela incorporação da tecnologia no cotidiano; c) saturação da mídia tradicional e fragmentação da audiência e, como conseqüência, a busca por maior impacto e repercussão da mensagem pelo boca a boca, também conhecido como buzz marketing e marketing viral; d) relevância do conteúdo como critério criativo, em vez da imposição da única proposição de venda da marca; e) a integração da publicidade com entretenimento (advertainment, advergaming, product placement); f) convergência de serviços de telecomunicação e comunicação por uma mesma empresa fornecedora (por ex. integração de serviços de telefonia celular, provedor de internet e TV a cabo).

de nome". Conferir em ARAUJO, A.C.; TELLES, A. O conceito de novas mídias e a utilização das mídias na publicidade. Latin American Journal of Development, v.3, n.4, p. 1899, 11 jul. 2021.

${ }^{5}$ Rafael Sampaio, ao fazer um balanço do século XX para o marketing, identificou três gerações da atividade ( 1 - ajudar a vender; 2- ajudar a fazer o melhor para o consumidor; 3- adaptar a empresa para o mercado) e propôs como desafio ao século seguinte uma abordagem sistêmica da atividade com os conceitos de ecomarketing e ecossistemas do mercado, segundo os quais as empresas deveriam estabelecer e cultivar relacionamentos mutuamente rentáveis com diferentes grupos do meio ambiente mercadológico como, por exemplo, governo, comunidade, cidadão, opinião pública, fornecedores, parceiros, revendedores, trade, acionistas, funcionários, não-consumidores, influenciadores e consumidores. SAMPAIO, R. EcoMarketing. Revista About. Edição especial 1995. 72p. 
O objetivo deste trabalho é discutir os pressupostos que alicerçaram a atividade publicitária, sobretudo a partir dos anos 50, quando os profissionais começaram a organizar o conhecimento prático em treinamentos internos e cursos específicos ${ }^{6}$, e as transformações impostas pelo impacto do uso doméstico de novos meios tecnológicos de acesso e compartilhamento de informações e as possibilidades de relacionamento daí decorrentes, dos consumidores entre si e com as marcas; transformações que estão obrigando profissionais e acadêmicos ligados ao setor a reverem alguns desses pressupostos tradicionais para reafirmá-los ou abandoná-los em nome de uma nova ordem que, ainda, em minha opinião, é prematuro descrever como certa, pois o trabalho de transformação ainda está em evolução, mas que já desponta como tendência.

Para ilustrar minha visão de como anda a publicidade nesse cenário de tensões entre o velho e o novo, utilizarei a história da marca Devassa Bem Loura, do grupo Schincariol, que tem conseguido aliar eficientemente esquemas conhecidos de criação publicitária, como por exemplo, o endosso da marca por celebridades e a associação do produto com sensualidade a técnicas inusitadas de difusão como a utilização integrada de TV, internet, rede social, comunicação boca a boca, mídia espontânea e ações de ativação, em dois momentos relevantes - 2010 e 2011- quando a marca provocou buchicho nas principais emissoras de notícias, gerais e especializadas, ao utilizar respectivamente as imagens de Paris Hilton ${ }^{7}$ e de Sandy ${ }^{8}$ como garotas propaganda do jeito de ser Devassa, ou melhor, dos jeitos possíveis de personificar a imagem de marca.

Algumas pressuposições que alicerçaram a atividade publicitária no século XX são desafiadas pelo case e outras são reiteradas ou atualizadas. Entre os pressupostos desafiados, destacamos os seguintes: (1) Publicidade é a principal disciplina de promoção da marca e (2) Publicidade é fazer comercial de TV. Entre as proposições que ainda hoje permanecem recorrentes nas práticas criativas profissionais, destacamos duas, interligadas: (3) Sexo, humor e celebridade em publicidade garantem atenção e (4) Emoção pega o consumidor. Vejamos com mais detalhes como o antigo e o novo conviveram nas duas campanhas da marca de cerveja, com Paris Hilton em 2010 e com Sandy em 2011, agora consideradas clássicas.

\footnotetext{
${ }^{6}$ Entre os anos 20 e 50, as agências de publicidade, como as pioneiras N.W.Ayer e J.W.Thompson, foram a principal referência de formação publicitária; em 1951 surgiu o primeiro curso regular promovido pela Escola de Propaganda do Museu de Arte de São Paulo, situado no antigo prédio dos Diários Associados, na Rua 7 de Abril. Cf. FIGUEIRA NETO, A.; SOUZA, S. A formação em propaganda. In: AQUINO, V. (org.). A USP e a invenção da propaganda 40 anos depois. São Paulo: Fundac, 2010, p. 73-92.

${ }^{7}$ Paris Whitney Hilton (1981) é socialite, atriz, cantora e empresária norte-americana, herdeira da rede de hotéis Hilton, e se notabilizou por protagonizar escândalos na mídia internacional.

${ }^{8}$ Sandy Leah Lima (1983) é cantora brasileira bem-sucedida e tem fama de garota certinha.
} 


\section{A CAMPANHA DE LANÇAMENTO DE DEVASSA BEM LOURA COM PARIS HILTON.}

A Agência $\operatorname{Mood}^{9}$, uma agência paulista especializada em promoção e ativação de marca, inaugurou em 7 de fevereiro de 2010, um domingo, uma campanha de lançamento da versão Devassa Bem Loura, uma cerveja artesanal carioca adquirida pelo grupo Schincariol em 2007. Vale lembrar que a marca Devassa já existia desde $2001^{10}$ e era distribuída principalmente por meio das cervejarias homônimas, no Rio de Janeiro e em São Paulo, mas foi com a campanha de lançamento da modalidade pilsen Bem Loura que a marca ganhou notoriedade nacional.

O teaser $^{11}$, em formato de comercial de televisão, foi veiculado durante o Big Brother Brasil (BBB10), um reality show produzido pela Rede Globo de Televisão, em São Paulo e Rio de Janeiro, mostrando a seguinte sequência de cenas: um fotógrafo, em seu apartamento/estúdio tenta, em vão, capturar o rosto de uma vizinha no prédio em frente, por meio de uma potente máquina fotográfica. Ela é loira e veste um microvestido preto. Percebendo o voyerismo de seu vizinho fotógrafo, ela o provoca e faz poses que lembram as antigas pin-ups ${ }^{12}$ americanas dos anos 50, mas os movimentos são rápidos e o fotógrafo só consegue registrar suas pernas bem torneadas, suas costas, o movimento de seus cabelos... Ele não consegue tirar uma foto do seu rosto. Ao rever, no display de sua máquina, os instantâneos tirados, ele vê um frame com a frase "Bem misteriosa" escrita em neon vermelho. O filme termina com o close do perfil do rosto do fotógrafo, um misto de desapontamento e curiosidade estampado na face e, logo abaixo, o letreiro <www.bemmisteriosa.com.br>. Apenas isto; nenhuma

\footnotetext{
${ }^{9}$ Agência Mood (www.agenciamood.com.br), na ocasião das campanhas, estava situada em São Paulo e era liderada pelos sócios Antonio Cruz Neto, Luiz Lara, Aaron Sutton e Fernando Lara. Era especializada na comunicação 3D que integrava promoção, propaganda, eventos, design, ponto de venda, ativação de marca, entre outras disciplinas de comunicação de marca. Hoje, a marca Devassa, fabricada pelo grupo Heineken, tem suas campanhas assinadas por HNK LAB, operação da WPP montada a partir da joint venture entre Grey, Ogilvy e Wunderman Thompson.

${ }^{10}$ É controversa a data de origem da cerveja de marca Devassa. Na publicação O livro da cerveja de Tim Hampson (p.315) o ano de lançamento da cerveja Devassa aparece como 2001 e o do bar Devassa como 2002, datas que coincidem com a história contada no site da marca <www.devassa.com.br>. No blog O mundo das marcas, disponível em <http://mundodasmarcas.blogspot.com/2008/05/cerveja-devassa.html> a história da marca registra seu início em 2003 quando foi fundada a União das Devassas Cervejaria Ltda (UDC), com a entrada de Joca Muller na sociedade já formada um ano antes por Marcello Macedo (Cello) e Marcelo do Rio em um bar no Leblon, Rio de Janeiro, batizado de Cervejaria Devassa, onde já serviam uma fórmula exclusiva de cerveja, encomendada e fabricada pelo mestre cervejeiro André Nothaft. Considerada uma cerveja de qualidade europeia e sabor refinado, a marca chamou a atenção do grupo Schincariol, que acabou por adquirir $70 \%$ da UDC em 2007, por R\$ 30 milhões. O grupo assumiu as marcas da UDC, a unidade de produção e a estrutura de distribuição; os antigos sócios Marcelo do Rio e Cello Macedo continuaram como gestores das franquias da Cervejaria. Em 2010, o grupo Schincariol investiu R \$ 100 milhões para o lançamento da Devassa Bem Loura, uma cerveja pilsen com um sabor mais próximo da cerveja que o brasileiro está acostumado a beber, comercializada nas versões lata (alumínio), garrafa $(600 \mathrm{ml})$ e chope. Em 2017, a marca foi vendida para o grupo Heineken.

${ }^{11}$ Técnica criativa que subverte o código da formulação publicitária ao omitir, propositadamente, o nome do patrocinador , bem como o nome da marca envolvida na mensagem enigmática e, assim, engajar o telespectador no desvendamento do mistério midiático proposto.

${ }^{12} \mathrm{O}$ termo pin-up surgiu nos EUA, nos anos 40, para designar as mulheres de papel que, afixadas nos armários dos soldados norte-americanos, os animavam durante a Segunda Guerra Mundial. Pintadas sobre as fuselagens dos aviões de combate, elas se tornaram símbolos de boa sorte e uma referência iconográfica do gênero.
} 
marca de patrocinador, nenhuma locução em off, apenas uma trilha musical marcante ${ }^{13}$ e um endereço na internet.

Digitando o endereço <www.bemmisteriosa.com.br> na internet, os internautas se deparavam com uma página em tom avermelhado com a imagem central de um pequeno buraco de fechadura e com a seguinte chamada verbal: "Ela está chegando. Ela é bem misteriosa. E vai deixar você bem curioso. Use o twitter para espiar. Quanto mais twitts você postar com a tag \#bemmisteriosa mais próxima fica a fechadura. Participe e incentive seus amigos a fazer o mesmo”. É exatamente nessa integração entre a inserção de comercial na TV, para atingir grande audiência, e o desafio na internet em formato de charada, dirigido a comunidades virtuais, que reside a novidade na utilização do teaser.

$\mathrm{O}$ mistério foi resolvido graças à reação e envolvimento de internautas e twitteiros ${ }^{14}$ que, após 48 horas, já davam a notícia de que a tal loira no buraco da fechadura era Paris Hilton fotografada por J.R. Duran para uma das marcas pertencentes ao grupo Schincariol. Nos anos 70, um teaser poderia levar até 15 dias para ser resolvido e isto por iniciativa da empresa promotora!

Mistério resolvido, uma nova mensagem na página digital convidava os internautas de <www.bemmisteriosa.com.br> a acompanhar o desenrolar da campanha com os seguintes dizeres: “Vocês estavam bem curiosos, né? Mas ainda não acabou... No dia 12 de fevereiro, no intervalo do Jornal Nacional vocês vão ver muito mais. E se você não mora no Rio ou em São Paulo vai poder ver acessando www.devassa.com.br a partir do mesmo horário. Bem irreverente. Bem Loura. Bem Devassa. O mistério acabou. Mas ainda há muito mais esperando por você. " Um uso inusitado: uma página da internet anunciando o anúncio em televisão ou na internet!

\subsection{O FILME-REVELAÇÃO DO TEASER E A AÇÃO DO CONAR}

O filme-revelação de 60 segundos foi veiculado a partir do dia 12 de fevereiro nos estados do Rio de Janeiro e de São Paulo e na página da internet <www.devassa.com.br> para os demais estados brasileiros, conforme informação dada anteriormente no site <www.bemmisteriosa.com.br>.

Seguindo narrativa e personagens principais do teaser, a história se desenvolve com o fotógrafo vendo sua vizinha pela janela e tentando fotografá-la outra vez. Ela abre uma geladeira e pega uma latinha. É a cerveja Devassa. Ela olha em direção ao fotógrafo e passa a lata pelo pescoço. A seguir, o fotógrafo bate outras fotos e fica feliz, pois dessa vez consegue capturar seu rosto. A loira passa a

\footnotetext{
${ }^{13}$ A trilha sonora utilizada é original do filme The man with the golden arm (O homem do braço de ouro), de Elmer Bernstein, estrelado por Frank Sinatra e premiado com um Oscar em 1955.

${ }^{14}$ Twitter é um servidor de microblogging e seus praticantes são chamados aqui de twitteiros. São pessoas comuns que usam a rede social para comunicar o que estão fazendo no momento, para dar opiniões sobre fatos e pessoas que as interessam, enfim, um espaço resumido de 140 caracteres que pode levar muitas outras pessoas a seguir seus recados, ampliando a conversação sobre a marca na internet.
} 
cerveja pelo seu microvestido preto e continua a dançar lentamente, de forma sensual. Da praia e de locais vizinhos, jovens, velhos, ambulantes - pessoas comuns maiores de 18 anos - olham para a janela e aplaudem, elevando copos de cerveja em saudação à loira da janela que, enfim, abre a lata e pronuncia o nome da cerveja: Devassa! Ao fundo, à direita da tela, a imagem do Pão de Açúcar, na cidade do Rio de Janeiro.

O filme ficou apenas duas semanas no ar, pois teve sua veiculação suspensa pelo CONAR, Conselho Nacional de Autorregulamentação Publicitária, em 26 de fevereiro, por conta de queixas registradas em nome da Secretaria Especial de Políticas para as Mulheres, órgão ligado à Presidência da República, da Cervejaria Itaipava, marca concorrente, e de alguns outros consumidores que se sentiram ofendidos com o apelo sensual do comercial. A suspensão da veiculação do filme por televisão, site e impressos foi confirmada em 31 de março, durante reunião mensal do órgão, na qual foi analisada a defesa elaborada pelo anunciante e sua agência; por unanimidade, o comercial foi considerado abusivo em sensualidade e desrespeitoso para com as mulheres (CONAR, 2010).

A Agência Mood, então responsável pela campanha, reagiu com humor à decisão e substituiu o filme censurado por outro, (terceiro da série) em que a grande estrela é a própria embalagem da cerveja com a adição de uma tarja preta irreverente sobre os seios da bonequinha retro desenhada no rótulo da garrafa. O rosto de Paris Hilton aparece somente no final pronunciando o nome da marca.

A partir de 16 de abril, um quarto filme passou a ser veiculado nas emissoras de TV, para agradecer aos consumidores e anunciar "Ela pegou! ”. O filme, montado com as mesmas cenas do filme-revelação, suprimiu as sequências filmadas com Paris Hilton em Los Angeles e manteve as tomadas filmadas no Rio de Janeiro, com a trilha musical original e a locução em off fazendo um balanço da vitória: "Ela foi vista por mais de 2 milhões de pessoas na internet. Ela foi a mais comentada no carnaval. Ela foi assunto na imprensa nacional e internacional. Agradecemos a você que experimentou, pediu e fez da "Devassa Bem Loura” um sucesso! Ela pegou. Bem pedida, bem loura, Devassa. ",

Muitos artigos opinativos foram publicados durante todo o mês de março na mídia especializada e no jornalismo diário. Renato Janine Ribeiro, professor titular de ética e filosofia na USP, convidado a dar sua opinião ao Caderno Mais da Folha de S.Paulo disse, em alusão à ação do CONAR, que a "linha de corte depende, muito, do grau de mobilização dos que se sentem ofendidos" (RIBEIRO, 2010, p.4). No mesmo artigo, reconhece que as mulheres são convertidas em coisa, "mulher-garrafa", e em objeto de consumo pelas campanhas de cerveja e que a defesa à propaganda com Paris Hilton apontaria para o desgaste do erotismo na sociedade atual e para a redução de sua capacidade de imaginar, o que seria lamentável. 
Lúcia Santaella, professora da PUC-SP, em outro artigo do mesmo Caderno, envereda por outro aspecto ao lembrar que "A publicidade funciona como termômetro que marca a temperatura dos valores culturais. Sem a sugestão, o apelo e o empréstimo de valores que estão impregnados na cultura de um povo, o discurso publicitário seria como carne sem tempero" (SANTAELLA, 2010, p.5).

\section{SINERGIA ENTRE DIFERENTES DISCIPLINAS DE MARKETING}

A Agência Mood planejou, concebeu e produziu todas as peças da campanha de lançamento de Devassa Bem Loura - dos rótulos aos anúncios, integrando diferentes disciplinas de comunicação de marca, todas bem integradas sob o conceito contemporâneo de comunicação 3D ou comunicação integrada.

A parte publicitária da campanha envolveu o desenvolvimento de filmes para TV e internet; spots para rádio, anúncios impressos e ações no meio digital; a parte do design se ocupou, especificamente, com a reformulação visual do site, com o redesenho da frota de veículos e das peças concebidas para decorar ponto de venda; a cenografia ficou a cargo do arquiteto Marcelo Rosenbaum na ambientação do Espaço Devassa, camarote montado na Av. Marquês de Sapucaí durante o carnaval carioca; o aspecto promocional envolveu ação de ativação nas praias do Rio de Janeiro, durante o mês de fevereiro e intervenção urbana durante os jogos da copa em junho, e a contribuição da assessoria de imprensa se deu, sobretudo, pela forma como a imprensa foi comunicada sobre camarote da Schincariol e a visita de Paris Hilton á cidade do Rio de Janeiro.

O conceito criativo que integrou todas as facetas da campanha se apoiou num tripé formado por: (a) o adjetivo Devassa utilizado como nome substantivo em várias versões da cerveja e nos bares próprios; (b) o adjetivo loura, termo usado principalmente na França e na Bélgica para designar uma cerveja douradae (c) o uso de celebridade, a americana Paris Hilton, para apresentar o produto, na tradição mais pura da publicidade de apresentação com figura do apresentador.

Paris Hilton, ao materializar a imagem da mulher-garrafa, metáfora de cerveja gostosa, encarnou o antigo em publicidade, o clichê que atrai os homens e desagrada as mulheres que se percebem diminuídas ou coisificadas.

\section{RECEITA DE FÉ DA MARCA DEVASSA}

Lorente (1991, p.27-30) diz que as marcas que mais triunfam são aquelas capazes de gerar atos diários de fé no mercado e que a fé comercial se constrói exatamente com os mesmos ingredientes presentes nos grandes fenômenos de fé da história da humanidade: (1) uma ideia clara, simples, de promessa de benefício; (2) uma argumentação esquemática elementar, apta a ser entendida por todos; 
(3) signos externos constantes e imprescindíveis na tarefa de traduzir o intangível e (4) uma hierarquia de poder que define e defende a fé.

Desde seu nascimento, em 2001/2, a marca Devassa tem pautado sua comunicação por esta receita de fé, com o uso consistente e reiterado de alguns elementos verbais e visuais que se mantiverem constantes em várias ações de marketing ao longo dos anos e que constituem seu DNA, conforme o Manifesto que simboliza o universo semântico da marca:

\begin{abstract}
Uma cerveja que se autoproclama Devassa deve ser no mínimo autêntica. Porque assume tudo o que as outras cervejas gostariam de ser, mas morrem de vergonha. Devassa é bem alegre, tem aquele astral que atrai coisas boas, pessoas interessantes e papos divertidos. Pedir uma Devassa tem a dose certa de segundas intenções. Quem bebe Devassa procura liberdade. Nada de fazer tipo, caras e bocas, fingir ser o que não é. Devassa é bem espirituosa, te pega pelo colarinho, te seduz pelo aroma e faz você se apaixonar de vez pelo sabor. Tanto que muita gente não resiste à tentação. E assim como a cerveja, Devassa tem seu irresistível chope - cru, não-pasteurizado e sempre fresquíssimo. Além da suavidade e do sabor inconfundível, tem um creme que é pura luxúria. Bastam dois a três dedos para garantir uma legião de fãs. Enfim, quem conhece sabe. Com Devassa a vida fica bem gostosa.

Bem gelada. Bem refrescante. Devassa. A cerveja Bem Devassa. ${ }^{15}$
\end{abstract}

Apoiado no fato de que cervejas do tipo pilsen são chamadas na Europa de loura, o manifesto desenvolve sua argumentação sobre os recursos retóricos do duplo sentido e da metáfora personalizante, por meio dos quais loura se transforma em loira e o termo de.vas.sa (F. subst. sindicância, inquérito) é assumido em sentido adjetivo de.vas.so (adj. destituído de valores morais; de comportamento desregrado ou imoral - AURÉLIO, versão eletrônica). Porém inversamente ao que recomendam os bons costumes, o Manifesto nos leva a aceitar que ser devasso significa ser autêntico, um valor a ser cultivado.

O leitor é levado, de forma clara e simples, a entender o benefício principal que o consumo do produto promete: beber uma cerveja Devassa é tão prazeroso quanto se deixar seduzir por uma loira gostosa. E é igualmente simples deduzir o raciocínio esquemático que se segue: ambos os prazeres tomar uma cerveja gelada ou se apaixonar por uma loira gostosa - não merecem resistência; pelo contrário, mostram que você é autêntico e não tem receio de se deixar levar pela sensação do prazer sensorial. Então você é o cara e se transforma em modelo a ser seguido. E Devassa ganha status de nome substantivo, marca de prestígio.

${ }^{15}$ Manifesto Devassa no site oficial da marca em 2010, hoje indisponível. 


\section{ELEMENTOS DE IDENTIDADE: MARCA GRÁFICA E SLOGAN}

A marca gráfica de Devassa faz uma releitura das tradicionais pin-ups americanas que se popularizaram pelas mãos de ilustradores como o americano Gil Elvgren (1914-1980), sem dúvida o mais ilustre representante do gênero do século XX (www.gilelvgren.com).

A nudez sugerida e nunca efetivada é o ponto chave que caracteriza o gênero pin-up de ilustração, que nos anos 40 se tornou popular entre os soldados norte-americanos e foi incentivada pelas autoridades militares como arma secreta para reforçar o moral dos combatentes.

No Brasil, o ilustrador das pin-ups foi José Luiz Benício da Fonseca, ou simplesmente Benício, gaúcho de Rio Pardo, que começou sua carreira aos 16 anos como aprendiz de desenhista em uma agência de publicidade de Porto Alegre e acabou se notabilizando pelas inúmeras ilustrações que fez para as capas de romances policiais da editora Monterrey e pelos cartazes de divulgação das pornochanchadas, gênero de comédia de costumes que dominou o cinema brasileiro entre as décadas de 1960 e 1980 (JUNIOR,2006).

A marca gráfica de Devassa, a bonequinha retrô como é conhecida, apresenta os mesmos ingredientes das pin-ups: é, ao mesmo tempo, provocante, sensual, sem ser vulgar ou explícita. Na versão Bem Loura, ela aparece estilizada e em alto-contraste.

Em relação ao slogan, durante bom tempo as cervejas e cervejarias Devassa utilizaram o grito de guerra "Um tesão de cerveja”, que apesar de ousado, nunca foi denunciado ao CONAR por ser ofensivo à sociedade. Com o lançamento da cerveja Bem Loura, este slogan foi substituído por "Bem Loura. Bem Devassa”, enfatizando o duplo sentido entre cerveja loura e loira devassa.

Em 2007, uma promoção criada pela agência McCann Erickson do Rio de Janeiro para a Cervejaria Devassa, produziu calendários da marca utilizando, em cada mês, ilustrações selecionadas da obra de Carlos Zéfiro ${ }^{16}$, o mestre dos quadrinhos pornô, para firmar o conceito Um tesão de cerveja.

Os elementos de identidade associados à figura de Paris Hilton estiveram presentes no site da marca durante a vigência da campanha estrelada pelo modelo, de 7 de fevereiro de 2010 até 28 de fevereiro de 2011, quando a Agência Mood lançou uma nova campanha com a cantora brasileira Sandy, uma personalidade midiática oposta à Paris Hilton, porém estratégica no sentido de consolidar os atributos simbólicos da marca e, ao mesmo tempo, expandi-los para outros segmentos de público, um pouco mais conservadores que o carioca.

\footnotetext{
${ }^{16}$ Carlos Zéfiro foi o pseudônimo de Alcides Aguiar Caminha (1921 - 1992), funcionário público carioca que, em atividade paralela, foi considerado o maior desenhista pornográfico do país. Ilustrou e publicou cerca de 500 histórias em quadrinhos, de cunho erótico, chamados de catecismos, vendidos em bancas de jornal.
} 
A campanha Devassa Bem Loura de 2010 contou com um total de sete versões de filmes comerciais ${ }^{17}$, dos quais seis foram estrelados pela celebridade americana.

O carnaval carioca foi um momento muito oportuno para a estreia do camarote Devassa na avenida Sapucaí, em substituição ao camarote Nova Schin, que vigorou de 2004 a 2009, estabelecendo, dessa forma, o momento de renovação anual da marca. Assim, no carnaval de 2011, o camarote Devassa recebeu a nova musa da marca, Sandy, embalada no tema Todo mundo tem seu lado Devassa, que revestiu igualmente site oficial da marca; site da Agência Mood, materiais de merchandising, marchinha de carnaval e filmes comerciais que foram veiculados durante as noites televisivas de março do presente ano.

\section{A CONTINUIDADE DA MARCA COM SANDY NO PAPEL DE GAROTA-PROPAGANDA}

Lançando mão dos mesmos esquemas de comunicação 3D, a Agência Mood provocou mais uma vez buchicho na mídia e nas comunidades virtuais, ao convencer Sandy a tingir seus cabelos para ser a nova loira da campanha Devassa do verão de 2011.

Vestindo figurino semelhante ao que imortalizou Liza Minnelli na pele da personagem Sally Bowles no filme americano Cabaret de 1972, dirigido por Bob Fosse e que lhe rendeu o Oscar de melhor atriz em 1973, Sandy entra em cena de costas no comercial, ao som da mesma trilha musical que caracterizou os anúncios da marca no ano anterior (O Homem do Braço de Ouro, de 1955). Enquanto o locutor convida o público a conhecer o outro lado da personagem, ela vira de frente, abre uma garrafa de cerveja na quina do balcão, lança a cartola para a plateia e começa a dançar, acompanhada pela mensagem: "Todo mundo achava que ela era comportadinha, boa menina, dormia cedo até conhecerem um outro lado dela. O lado Devassa. Todo mundo tem um lado descontraído, tem um lado desencanado, desinibido e tem tudo a ver com uma Devassa Bem Loura. Bem suave. Bem gostosa. Todo mundo tem um lado Devassa. Produto destinado a adultos. "

\footnotetext{
${ }^{17}$ Os filmes encontram-se disponíveis no Youtube www.youtube.com.br e são: 1- teaser Bem misteriosa, veiculado a partir de 7 de fev.2010; 2-o filme-revelação de Devassa Bem Loura com Paris Hilton, que ficou no ar entre 12 e 26 de fevereiro de 2010, quando foi censurado pelo CONAR; 3- filme resposta da marca à censura, com o símbolo gráfico da Devassa tarjado; 4- Ela pegou, filme veiculado a partir de 16 de abril, comentando que a marca havia sido vista por 2 milhões de pessoas na internet; 5- Ela voltou, filme com Paris Hilton dirigindo um caminhão de entregas de Devassa pela praia de Copacabana e com os seguintes dizeres: Você pediu e ela voltou trazendo mais. Bem servida. Bem gelada. Bem loira. Devassa cerveja bem devassa. Produto destinado a adultos, veiculado a partir de agosto de 2010; 6- filme de divulgação da ação promocional Alô Paris Hilton, realizada por meio de sorteios vinculados a títulos de capitalização e autorização da SUSEP, em que 200 ganhadores poderiam ganhar smartfones e, entre eles, um poderia viajar para Los Angeles com quatro amigos para conhecer a estrela Paris Hilton; filme veiculado durante vigência da promoção de 17 de set. a 24 de nov. de 2010; 7- filme de verão, sem a presença de Paris Hilton, intitulado Contágio, no qual as pessoas na praia, batucando ou assobiando música tema da campanha, compram latinhas da cerveja dos vendedores ambulantes e reclamam quando estoque acaba; veiculado durante o mês de dezembro de 2010.
} 
Este filme ${ }^{18}$ foi ao ar apenas no dia 1 de março de 2011 e estampou os noticiários do dia seguinte, com fotos e depoimentos da cantora, em um bem planejado trabalho de marketing e de assessoria de imprensa. Mantendo a trilha sonora de O Homem do Braço de Ouro e a mesma paleta de cores (preto, branco, vermelho e tons quentes alaranjados), a campanha fez uma transição suave para o segundo momento da história da marca, em que a sensualidade das curvas de Paris Hilton dentro de um tubinho preto cede a vez para a silhueta dançante de Sandy, recatadamente desinibida dentro de um conjunto de short e camiseta.

Lançada a identidade da nova protagonista (endossante no papel dela mesma!) a marca veiculou durante o mês de março mais três versões de 30 segundos $^{19}$, nas quais Sandy aparece dando seu recado - Todo mundo tem seu lado Devassa- enquanto grupinhos de jovens, homens e mulheres, em cenários diversificados (por exemplo, dentro de um bar, na praia, durante um churrasco ao lado da piscina, no supermercado) dançam a música Conga Conga Conga ${ }^{20}$ para mostrar o outro lado, aquele mais descontraído, que reuniões informais entre amigos inspira, legitima e encoraja.

Tal qual a campanha do ano anterior, todas as peças foram embasadas em uma nova versão do manifesto da marca:

\begin{abstract}
Nós vivemos numa sociedade cheia de regras. Desde pequenos, aprendemos a deixar o cotovelo fora da mesa, a falar baixo, a cumprir todas as obrigações de uma vida em sociedade. Aí a gente cresce e descobre que não poder falar de boca cheia também faz a gente engolir um monte de sapos.

Aos poucos, todas essas regras vão tirando a nossa criatividade e alegria. Mas ao mesmo tempo, algumas coisas, algumas situações nos fazem sair desse cotidiano do mundo bem-comportado. Nossos amigos, nossos fins de semana, nossos happy hours, nossas saideiras nos tiram da caixa.

É quando a gente pode mostrar quem, de verdade, a gente é. É nessas horas que agente fala duas vezes antes de pensar, que a gente perde a compostura, mas não perde a piada.

É quando a gente paga mico, quando a gente pisa na bola, quando a gente faz aquilo que tem vontade de fazer. E aí que aparece o outro lado de cada um de nós. O nosso lado descontraído, o nosso lado despirocado, o nosso lado desencanado, o nosso lado diferente. Porque, no fundo, todo mundo tem um lado Devassa. ${ }^{21}$
\end{abstract}

\footnotetext{
${ }^{18}$ Disponível no youtube http://www.youtube.com/watch? $\mathrm{v}=33 \mathrm{k} 1 \mathrm{zRWeUtQ} \& \mathrm{NR}=1$ Sandy em Todo mundo tem seu lado Devassa. Acesso em: abr. 2011.

${ }^{19}$ Depois do filme de lançamento da Sandy, ela protagoniza o segundo filme Qual é o seu lado Devassa? convidando outras pessoas a dançar dentro de um bar noturno com seguinte apelo: "Todos mundo tem um lado descontraído, desinibido, descolado. Todo mundo tem um lado Devassa. Qual é o seu?”; no terceiro filme Um brinde ao seu lado Devassa Sandy apresenta o produto, dança no balcão de um bar e mostra outras pessoas na praia e piscina dançando ao som de Conga Conga Conga; na quarta versão Afinal, todo mundo tem seu lado Devassa, as cenas de Sandy dançando Conga em um bar são mescladas a cenas em que grupos de jovens dançam descontraidamente dentro de corredores de um supermercado, motivo que possibilita a exibição das novas geladeiras de PDV desenhadas para integrar a campanha deste ano.

${ }^{20}$ Música de Mister Sam, celebrizada pela performance da cantora brasileira Gretchen nos anos 70.

${ }^{21}$ O lado Devassa. Manifesto Disponível em : http://www.devassa.com.br/bemloura/index.html?isMaior=true\#/manifesto/ Acesso em: 2 mar.2011. Atualmente indisponível.
} 
Por trás dos dois manifestos, fica evidente o objetivo de associar a marca a pessoas que não tem medo de se mostrar como são, ainda que esta autenticidade seja apenas um lado de sua personalidade; afinal, em publicidade, qualquer razão pode virar um bom argumento!

Atualmente, depois de ser vendida ao grupo Heineken, e com a proibição de associar bebidas alcoólicas a desempenho sexual ou esportivo, a publicidade da Devassa elegeu a cantora Iza sua musa inspiradora e com ela tem desenvolvido o projeto de descoberta de novos talentos associados à criatividade tropical. ${ }^{22}$

\section{CONSIDERAÇÕES FINAIS: COMO ANDA A PUBLICIDADE?}

A publicidade está passando por mudanças paradigmáticas e o fato é que ela não reina mais absoluta entre as disciplinas de comunicação do marketing; nem tampouco o consumidor se encaixa no papel de receptor submisso das mensagens comerciais das décadas iniciais da atividade profissional.

Os pressupostos que sustentaram a comunicação publicitária devem ser revistos e atualizados, pois alguns deles já não dão mais conta de explicar a atividade profissional tal qual ela foi praticada dos anos 50 até o início dos anos 90 (início da revolução digital) ou, como ela foi ensinada desde os primeiros cursos universitários no país.

A campanha Devassa Bem Loura mostrou o que pressuposto $\mathrm{n}^{\circ} 1$ que apresentamos na introdução deste trabalho - Publicidade é a principal disciplina de promoção da marca - é questionável. As fronteiras entre as disciplinas de comunicação estão cada vez mais indefinidas e novos formatos, híbridos, estão substituindo os formatos tradicionais de anúncios e comerciais. É possível afirmar que o impacto de audiência do teaser teria sido diferente se TV, internet, Twitter, imprensa, eventos, camarote, promoção, design e merchandising não tivessem se integrado em um mesmo conceito criativo respeitando, porém, as características linguísticas de cada meio.

O segundo pressuposto que apresentamos - Publicidade é fazer comercial de TV-também não se sustenta ante a concepção de comunicação em três dimensões que fundamentou a criação de Devassa Bem Loura nas suas duas fases iniciais. Em vez dele, podemos dizer que, se a TV fizer parte da mídia da campanha, os 30 segundos da TV devem apresentar alguma diversão, sob pena de nem serem percebidos no meio da transmissão dos programas.

O terceiro pressuposto - Sexo, humor e celebridade em publicidade garantem atenção- é exemplo de uma prática antiga que permanece constante ainda para muitas categorias de produto. No entanto, é importante frisar que sexo em propaganda, quando permitido pelo CONAR, aumenta recordação da marca apenas quando é relevante para a mensagem principal da marca. Devassa Bem

\footnotetext{
${ }^{22}$ Conferir em: https://www.youtube.com/watch?v=GwcvcTVbji0. Acesso em: 6 set.2021.
} 
Loura, condenada a sair do ar por excesso de apelo sensual e desrespeito às mulheres, dividiu opiniões e mobilizou ações de apoio à campanha. Bebidas alcóolicas associadas a mulheres bonitas, jovens e gostosas, atualmente estão proibidas pelo código publicitário, mas durante muito tempo fizeram parte do repertório cultural e suas campanhas eram curtidas como entretenimento e diversão, inclusive por outras faixas etárias que não as alvejadas pelas campanhas da marca em questão.

Quanto ao uso de celebridade em publicidade, o importante é a compatibilidade que deve existir entre ela, o público visado e a imagem de marca programada. A escolha de um protagonista célebre deve considerar dois aspectos de influência: (a) seu poder de atratividade e/ou (b) sua credibilidade junto ao público-alvo. A atratividade opera através de um mecanismo de identificação, enquanto a credibilidade funciona através de um processo de internalização. A celebridade considerada atrativa é capaz de fazer com que o público compartilhe um sentimento de familiaridade e simpatia, mesmo quando a similaridade entre eles não é o principal atributo. A credibilidade baseia-se na capacidade da celebridade em despertar a confiança do ouvinte ou, em fazê-lo reconhecer suas habilidades e experiência ${ }^{23}$.

Pelo avesso, a vida de escândalos e excentricidades da celebridade Paris Hilton favoreceu a credibilidade aos argumentos da marca (ser autêntica é não ter medo de se mostrar como é) transformando-a em exemplo de autoridade máxima ou stricto. Em sentido convergente, porém oposto, o contrato (milionário) de Sandy veio reforçar este mesmo argumento ao mostrar que a celebridade, então com 28 anos, estava madura para se mostrar integralmente como nunca foi antes (...e aí que aparece o outro lado de cada um de nós (...) o nosso lado diferente) a ponto de mudar a cor dos cabelos e dançar alguns embalos mais provocantes que o seu usual, assumindo o exemplo de uma autoridade lato segundo classificação de Figueiredo (2009, p.1-11).

O recurso a celebridades, aliás, reforça a manutenção do pressuposto publicitário que defende a emoção para engajar o consumidor (Emoção pega o consumidor). Mais que beber uma cerveja de qualidade, as campanhas mostraram que ser autêntico, fazer o que dá prazer, dar vazão aos sentidos e mostrar seu outro lado, descontraído, despirocado, desencanado e diferente são benefícios intangíveis tão importantes quanto as necessidades funcionais que os consumidores querem ver resolvidas pelo desempenho do produto.

\footnotetext{
${ }^{23}$ Oscilando entre atratividade e credibilidade, Celso Figueiredo distingue três níveis de autoridade para qualificar o uso de celebridade em propaganda: (a) autoridade stricto, quando a pessoa famosa é oficialmente expert em determinado tema; (b) autoridade lato, quando a celebridade não é especialista no assunto ou produto, mas exerce uma atividade que tangencia o conceito da campanha; (c) autoridade presença, quando o endossante é famoso, mas sem alguma identidade entre o personagem que encarna e o produto que apresenta ou exibe. Conferir em:FIGUEIREDO NETO, C. Úteis e Fúteis. Considerações sobre uso de celebridades em Publicidade. In: IINTERCOM. XXXII Congresso Brasileiro de Ciências da Comunicação, Curitiba, 2009, CD do evento, p.1-11.
} 
Os quatro pressupostos descritos acima e cotejados com o desempenho das duas fases da campanha Devassa Bem Loura, escolhida como case exemplar, sinalizam mudanças relevantes na maneira de se entender a publicidade e a comunicação de marca frente às transformações sociais em curso e organizam, em grandes linhas gerais, as tendências que tensionam atualmente a atividade e desafiam a prática profissional como a reflexão acadêmica. 


\section{REFERÊNCIAS BIBLIOGRÁFICAS}

ADLER, R.; FIRESTONE, C. A conquista da atenção: a publicidade e as novas formas de comunicação. São Paulo, Nobel, 2002.

AGÊNCIA MOOD ${ }^{3}$. Mas quem é a Mood? Site da agência publicitária responsável pela campanha de Devassa Disponível em: www.agenciamood.com.br. Acesso em: abr. 2011.

ARAUJO, A.C.; TELLES, A. O conceito de novas mídias e a utilização das mídias na publicidade. Latin American Journal of Development, v.3, n.4, p. 1891-1905, 11 jul. 2021.

AURÉLIO. Novo dicionário Aurélio. Versão eletrônica 5.11a da 3ª . Ed. De Século XXI. O dicionário da Língua Portuguesa, Editora Positivo Informática.

BENÍCIO ilustrador. Pin-ups. Site oficial do ilustrador José Luiz Benício. Disponível em: www.benicioilustrador.com.br. Acesso em: mai. 2010.

CAVALLINI, R. O marketing depois de amanhã. São Paulo: Digerati Books, 2006.

CCSP Clube de Criação de São Paulo. Devassa. Disponível em: www.ccsp.com.br. Acesso em: mai. 2010.

CLUBE de Criação do Rio de Janeiro. Devassa. Disponível em: www.ccrj.irion.com.br. Acesso em: mai. 2010.

CONAR. Conselho Nacional de Autorregulamentação Publicitária. Decisões dezembro 2010. Disponível em: www.conar.org.br. Acesso em:3 set.2021.

DEVASSA. Devassa bem loura. Site oficial da marca. Disponível em: www.devassa.com.br. Acesso em: mai. 2011. Atualmente: https://www.devassa.com.br/Campanha. Acesso em:8 set. 2021.

FIGUEIRA NETO, A; SOUZA, S. A formação em propaganda. In: AQUINO, V. (org.). A USP e a invenção da propaganda 40 anos depois. São Paulo: Fundac, 2010. p.73-92.

FIGUEIREDO NETO, C. Úteis e Fúteis. Considerações sobre uso de celebridades em Publicidade. In: IINTERCOM. XXXII Congresso Brasileiro de Ciências da Comunicação, Curitiba, 2009, CD do evento, p.1-11.

GIL ELVGREN. Great American Pin-Up Artist. About. Disponível em: http://www.gilelvgren.com/GE/intro.php . Acesso em: 8 set. 2021.

GRACIOSO,F.; WHITAKER,P. Propaganda Brasileira. São Paulo: Mauro Ivan editorial, 2004. HAMPSON, T. O livro da cerveja. Rio de Janeiro: Nova fronteira, 2009. (Devassa, p. 246-7, 315, 339)

JUNIOR, G. Benício: Um perfil do mestre das pin-ups e dos cartazes de cinema. São Paulo: CLUQ (Clube dos Quadrinhos), 2006. 
LORENTE, J. Uma marca se hace creando actos de fe. Cuadernos de Comunicación. N.101, México, jul.1991.p.27-30.

MUNDO das marcas: Cerveja Devassa. Blog de Kadudias. Disponível em:

http://mundodasmarcas.blogspot.com/2008/05/cerveja-devassa.html. Acesso em: 8 set.2021.

RIBEIRO, R.J. A devassa da devassa. Folha de S. Paulo, São Paulo, 7 mar.2010. Caderno MAIS, p.4.

ROSENBAUM Design. Devassa pelo avesso. Disponível em:

https://rosenbaumdesign.wordpress.com/2010/02/16/camarote-devassa-2010-2/ Acesso em: 8 set. 2021.

SAMPAIO.R. EcoMarketing. Revista About. Edição especial 1995.p.32-52.

SANTAELlA, L. Tiro pela culatra. Folha de S. Paulo, São Paulo, 7 mar.2010. Caderno MAIS, p.5. 